\title{
Alleviation of hyperglycemia in diabetic rats by intraportal injection of insulin-producing cells generated from surgically resected human pancreatic tissue
}

\author{
Jia-Fwu Shyu, Hwai-Shi Wang ${ }^{1}$, Yi-Ming Shyr ${ }^{2}$, Shin-E Wang ${ }^{2,3}$, Chia-Hsiang Chen ${ }^{1}$, Joo-Shin Tan ${ }^{1}$, \\ Meng-Feng Lin, Po-Shiuan Hsieh ${ }^{4}$, Huey-Kang Sytwu ${ }^{5}$ and Tien-Hua Chen ${ }^{1,2}$ \\ Department of Biology and Anatomy, National Defense Medical Center, Taipei 11490, Taiwan, ROC \\ ${ }^{1}$ Department of Anatomy, School of Medicine, Institute of Anatomy and Cell Biology, National Yang Ming University, No. 155, Section 2, Linong Street, \\ Taipei 11217, Taiwan, ROC \\ ${ }^{2}$ Department of Surgery, Veterans General Hospital, Taipei 11221, Taiwan, ROC \\ ${ }^{3}$ Institute of Clinical Medicine, National Yang Ming University, Taipei, Taiwan, ROC \\ ${ }^{4}$ Department of Physiology and Biophysics and ${ }^{5}$ Department of Microbiology and Immunology, National Defense Medical Center, Taipei 11490, Taiwan, ROC \\ (Correspondence should be addressed to T-H Chen at Department of Anatomy, School of Medicine, Institute of Anatomy and Cell Biology, National Yang Ming \\ University; Email: chen_th@vghtpe.gov.tw)
}

\begin{abstract}
Although islet transplantation holds promise for the treatment of diabetes, the scarcity of donor tissue remains a major drawback. The aim of this study is to generate insulinproducing cells from adult human pancreatic cells isolated from surgically resected pancreatic tissue. To isolate pancreatic endocrine precursor cells from 57 surgically resected pancreases, the cells were cultured and propagated in conditioned medium after which they were differentiated in Matrigel. The resultant cells were characterized using morphology, immunofluorescent studies, expression of differentiated pancreatic islet-specific genes using quantitative reverse transcription-PCR, and glucose-induced insulin secretion through analysis of C-peptide secretion. The relationships between propagation of insulin-producing cells and clinical variables of the donor were also analyzed. Finally, insulin-producing cell function was examined in streptozotocin-induced diabetic rats. Pancreatic endocrine
\end{abstract}

precursor cells were successfully cultured; insulin-producing cells cultured from soft pancreas parenchyma had a significantly higher success rate. Morphological examination revealed islet-like cluster formation upon transfer to Matrigel. The presence of the neural stem cell marker nestin, duct cell marker cytokeratin 19, and endocrine cell markers C-peptide and pancreatic and duodenal homeobox 1 , was also observed. In addition, glucose-stimulated C-peptide release was significantly increased in the insulinproducing cells. Furthermore, in diabetic rats, transplantation of insulin-producing cells reduced hyperglycemia. Isolated pancreatic endocrine precursor cells from surgically resected pancreatic tissue differentiated into insulin-producing cells and showed characteristics of functional endocrine cells. Thus, surgically resected pancreatic tissue may represent an alternative source of functional insulin-producing cells.

Journal of Endocrinology (2011) 208, 233-244

\section{Introduction}

Type 1 diabetes is a chronic disease which is characterized by absolute insulin deficiency (Nerup et al. 1970, Atkinson 2005). Since the discovery of insulin more than 80 years ago and with the advent of glucose monitoring, considerable advances in insulin therapy have occurred. However, insulin replacement therapy remains only part of the ultimate solution for the treatment of patients who have type 1 diabetes. Therefore, novel therapies that address the shortcomings of insulin replacement therapy, leading to the eventual cure of type 1 diabetes, should be pursued.

Diverse therapeutic strategies for type 1 diabetes, including pancreas transplantation (Larsen 2004, Ryan et al. 2006), islet transplantation (Shapiro et al. 2000), regeneration therapy (Yamaoka 2002), and cell-based gene therapy (Samson \& Chan 2006), have been reported. Because islet cell transplantation represents a less-invasive treatment strategy, it may be superior to whole pancreas transplantation. However, the paucity of donor pancreases and problematic harvest of sufficient islet cells from cadaverous donors remain the drawbacks to this therapeutic strategy. In previous studies, multiple donors as well as transplantations were required to achieve insulin independence, with a 1-year insulinindependent rate of $44 \%$ and only a $10 \%$ insulin-independent rate after a 5-year follow-up (Shapiro et al. 2003, 2006). Therefore, identification of new cell sources is necessary to develop future replacement strategies. 
Regeneration therapy represents an approach that could potentially cure type 1 diabetes when combined with cellbased gene therapeutic strategies and immune system modulation (Sytwu et al. 2003, Sung et al. 2004). In ex vivo regeneration therapy, the patients' own bone marrow stem cells are transiently removed and differentiated into $\beta$-cells in vitro (Lechner \& Habener 2003, Moriscot et al. 2005) whereas in vivo regeneration therapy uses the patients' own cells to regenerate impaired tissues (Zulewski et al. 2001, Gao et al. 2003). In vivo regeneration therapy is more cost-effective, has fewer side effects, and is more ethically and clinically acceptable; therefore, it may offer the greatest potential therapeutic value to diabetic patients, if effective protocols could be developed.

The $\beta$-cell mass within the adult pancreas possesses the ability to undergo limited regeneration following injury. Identifying the progenitor cells involved in this process and understanding the mechanisms leading to their maturation will open new avenues for the treatment of type 1 diabetes (Maria-Engler et al. 2004, Lin et al. 2006). Despite steady advances in determining the molecular mechanisms regulating early pancreatic development and $\beta$-cell regeneration, development of protocols and identification of determining factors to consistently produce successful cultures of pancreatic stem cells or $\beta$-cell progenitors have yet to be described (Dodge et al. 2009).

Although generation of functional neoislets has been reported from various adult human pancreatic tissues, including pancreatic islets (Lechner et al. 2005), nonislet pancreatic cells, discarded after islet isolation (Todorov et al. 2006), and exocrine cells (Rapoport et al. 2009), it remains to be determined whether these sources provide the amount of neoislets required for in vivo regeneration therapy for diabetic patients.
To identify and characterize a new cellular source for in vivo regeneration therapy in patients with type 1 diabetes, surgically resected human pancreatic tissue was obtained, and endocrine precursor cells were isolated, cultured, and characterized. Furthermore, donor characteristics were compared with insulin-producing cell culture success. Finally, insulin-producing cell function was examined in streptozotocin (STZ)-induced diabetic rats. Identifying a novel source of functional islet cells and determining the precise culture conditions required may represent a novel treatment strategy for patients with type 1 diabetes.

\section{Materials and Methods}

\section{Pancreatic endocrine precursor cell isolation and culture}

From June of 2004 to September of 2007, pancreatic tissue was obtained from patients undergoing pancreatic resection for pancreatic head cancer $(n=20,35 \cdot 1 \%)$, Amupla of Vater cancer $(n=15,26 \cdot 3 \%)$, common bile duct cancer $(n=6$, $10 \cdot 5 \%)$, duodenal cancer $(n=2,3 \cdot 5 \%)$, chronic pancreatitis $(n=3,5 \cdot 3 \%)$, and other lesions $(n=22,19 \cdot 3 \%$; Table 1$)$. Among the 57 donors, 41 males and 16 females were enrolled in this study; the average donor age was 64 years $( \pm 15 \cdot 4$ years; Table 1). After the resection, normal pancreatic tissue, which consists largely of the exocrine acini, interlobular ducts, and islets of Langerhans, was identified as tissue without cancer cell infiltration by a pathologist at the Taipei Veterans General Hospital.

The human pancreatic tissue was immediately immersed in solution $\mathrm{D}(0 \cdot 137 \mathrm{M} \mathrm{NaCl}, 5 \cdot 38 \mathrm{mM} \mathrm{KCl}, 0 \cdot 19 \mathrm{mM}$ $\mathrm{Na}_{2} \mathrm{HPO}_{4}, 0.205 \mathrm{mM} \mathrm{K}_{2} \mathrm{HPO}_{4}, 5.49 \mathrm{mM}$ glucose, $0.058 \mathrm{M}$ sucrose, $1 \%$ penicillin/streptomycin, and $0 \cdot 12 \%$ fungizone (Invitrogen)) to prevent degradation. The average size of

Table 1 Donor clinical characteristics with respect to insulin-producing cell culture success $(n=57)$. Data are shown as mean \pm s.D. for donor age, and $n(\%)$ for categorical data which includes age above or below 65 years old, sex, pancreas parenchyma consistency, and diagnosis of primary lesion

\begin{tabular}{|c|c|c|c|c|}
\hline & Total $(n=57)$ & Success $(n=20)^{\mathrm{a}}$ & Failure $(n=37)$ & $P$ value \\
\hline \multicolumn{5}{|l|}{ Characteristics } \\
\hline Age (years) & $64 \cdot 0 \pm 15 \cdot 4$ & $64 \cdot 6 \pm 14 \cdot 6$ & $63 \cdot 7 \pm 15 \cdot 9$ & \\
\hline$\leq 65$ years & $26(45 \cdot 6)$ & $8(40 \cdot 0)$ & $18(48 \cdot 6)$ & $0 \cdot 532(\mathrm{C})$ \\
\hline$>65$ years & $31(54 \cdot 4)$ & $12(60 \cdot 0)$ & $19(51 \cdot 4)$ & \\
\hline Sex, females (\%) & $16(28 \cdot 1)$ & $5(25 \cdot 0)$ & $11(29 \cdot 7)$ & $0 \cdot 704(C)$ \\
\hline \multicolumn{5}{|l|}{ Parenchyma consistency, $n(\%)$} \\
\hline Soft & $35(61 \cdot 4)$ & $17(85 \cdot 0)$ & $18(48 \cdot 6)$ & $0 \cdot 010 *(\mathrm{~F})$ \\
\hline Hard & $22(38 \cdot 6)$ & $3(15 \cdot 0)$ & $19(51 \cdot 4)$ & \\
\hline Diagnosis of primary lesion, $n(\%)$ & & & & $0 \cdot 070(\mathrm{~F})$ \\
\hline Pancreatic head cancer & $20(35 \cdot 1)$ & $5(25 \cdot 0)$ & $15(40 \cdot 5)$ & \\
\hline Ampula of Vater cancer & $15(26 \cdot 3)$ & $6(30 \cdot 0)$ & $9(24 \cdot 3)$ & \\
\hline Common bile duct cancer & $6(10 \cdot 5)$ & $3(15 \cdot 0)$ & $3(8 \cdot 1)$ & \\
\hline Duodenal cancer & $2(3 \cdot 5)$ & $0(0)$ & $2(5 \cdot 4)$ & \\
\hline Chronic pancreatitis & $3(5 \cdot 3)$ & $1(5 \cdot 0)$ & $2(5 \cdot 4)$ & \\
\hline Others & $11(19 \cdot 3)$ & $5(25 \cdot 0)$ & $6(16 \cdot 2)$ & \\
\hline
\end{tabular}

${ }^{*} P<0 \cdot 05$. C, using the $\chi^{2}$ test; $F$, using Fisher's exact test.

${ }^{a}$ Success was determined by formation of islet-like cell cluster and expression of PDX1 and C-peptide. 
pancreatic tissue obtained was $0 \cdot 5 \times 1 \times 2 \mathrm{~cm}$, weighing $0 \cdot 5-$ $2 \mathrm{~g}$. After the isolated tissue was minced, it was digested with $2 \mathrm{mg} / \mathrm{ml}$ Type V Collagenase (Sigma-Aldrich) for $30 \mathrm{~min}$ at $37^{\circ} \mathrm{C}$. The digested sample was then washed three times with cold DMEM/F12 (Invitrogen). Pancreatic duct cells, islets, and stem cells were isolated by centrifugation at $1200 \mathrm{~g}$ for $20 \mathrm{~min}$ at $4{ }^{\circ} \mathrm{C}$ in Histopaque $(1.077 \mathrm{mg} / \mathrm{ml}$; SigmaAldrich):DMEM/F12 gradients. The cells were aspirated from the Histopaque:DMEM interface and then washed with DMEM/F12. The isolated cells were then cultured with CMRL 1066 medium $(5.5 \mathrm{mM}$ glucose, Invitrogen) containing $10 \%$ fetal bovine serum, $1 \%$ penicillin/streptomycin, $100 \mathrm{ng} / \mathrm{ml}$ nerve growth factor (NGF, R\&D Systems, Minneapolis, MN, USA), $10 \mathrm{mM}$ nicotinamide (Sigma), and $25 \mathrm{ng} / \mathrm{ml}$ epidermal growth factor (EGF, Invitrogen). Thereafter, the cells were cultured for 7-10 days until reaching confluence. During the expansion phase, the culture medium was changed every 3 days. Cells intended for immunofluorescent labeling were cultured on glass coverslips.

This study followed the tenets and regulations described in the Declaration of Helsinki. This study was reviewed by the Institutional Review Committee of the Taipei Veterans General Hospital.

\section{Cell proliferation analysis}

Cell growth assays were performed using the CellTiter96 Aqueous One Solution Cell Proliferation Assay kit (Promega) following the manufacturer's instructions. Isolated pancreatic endocrine precursor cells were plated at concentrations of $10^{4}$ cells/well in 96-well plates. The growth rate was analyzed at days 3,5 , and 7 in the expansion phase. Absorbance was measured at a wavelength of $490 \mathrm{~nm}$, and the absorbance values of growth factor and serum-treated cells are presented as a percentage of the absorbance of untreated cells at day 3 .

\section{Pancreatic differentiation in Matrigel}

Cultured cells were trypsinized with $0 \cdot 05 \%$ trypsin/EDTA (Invitrogen), washed with serum-free DMEM/F12 (17.5 mmol/1 glucose), and seeded into 6-well culture dishes coated with Matrigel (BD Bioscience, Bedford, MA, USA) diluted $1: 10$ at a concentration of $1 \times 10^{6}$ cells/well for differentiation. The culture medium contained insulin, transferrin, sodium selenite + linoleic acid (ITS +1 , Sigma), $2 \mathrm{~g} / 1 \mathrm{BSA}$, and $10 \mathrm{ng} / \mathrm{ml}$ basic fibroblastic growth factor (bFGF, Invitrogen). Cells aggregated from monolayers to clusters. After 5-7 days culture in Matrigel, the gel layer was disrupted with a cell scraper. Cell clusters and Matrigel pieces were transferred to a large volume of prewarmed medium and individual cell clusters were handpicked with a fire-polished glass pipette. The cell clusters were then cultured in suspension 5 days in serum-free DMEM/F12 supplemented with ITS +1 . Dithizone staining was used to identify and quantify the zinc-containing islet cells (McNary 1954).
Samples undergoing quantitative real-time PCR analysis were collected from resected pancreatic tissue, and also at the end of the culture expansion, differentiation, and maturation phases. Immunostaining samples were cultured in DMEM/F12 supplemented with ITS +1 and $10 \%$ serum for two additional days for adherence to the glass coverslips. Samples to determine C-peptide secretion were collected at the end of the maturation phase.

Culture success was defined as the formation of islet-like cell clusters in Matrigel and the expression of pancreatic and duodenal homeobox 1 (PDX1) and C-peptide during the differentiation and maturation phases.

\section{Immunofluorescent staining and microscope analysis}

The cells were fixed in PBS containing 4\% paraformaldehyde, $2 \mathrm{mM}$ EGTA and $400 \mathrm{mM}$ sucrose at room temperature for $15 \mathrm{~min}$. Cells were then permeabilized using $0 \cdot 1 \%$ Triton $\mathrm{X}-100$ in PBS at room temperature for $1 \mathrm{~h}$, and blocked with $5 \mathrm{mg} / \mathrm{ml} \mathrm{BSA}$ and $10 \%$ goat serum in PBS for $1 \mathrm{~h}$. Cells were then incubated in blocking solution with primary antibody overnight at $4{ }^{\circ} \mathrm{C}$ after which they were washed in PBS for five times for $10 \mathrm{~min}$ each. Primary antibodies and dilutions were as follows: nestin mouse monoclonal antibody, 1:200 (Chemicon International, Temecula, CA, USA); Pdx1 rabbit polyclonal antibody, 1:500 (Chemicon International); C-peptide rabbit polyclonal antibody, 1:100 (Linco Research, St Charles, MO, USA); cytokeratin 19 (CK19) mouse monoclonal antibody, 1:200 (Dako, Carpinteria, CA, USA); Ki-67 mouse monoclonal antibody, 1:200 (Dako); and human nuclei mouse monoclonal antibody, 1:400 (Chemicon International). For detection of primary antibodies, AlexaFluor-488-conjugated (green, Molecular Probes, Inc., Eugene, OR, USA) or Cy-3-conjugated (red, Jackson Immunoresearch Laboratories, West Grove, PA, USA) secondary antibodies were used according to the manufacturer's instructions. Briefly, cells were incubated with secondary antibodies diluted 1:200 in blocking solution for $1 \mathrm{~h}$ at room temperature. Cell nuclei were visualized using TOTO-3 diluted 1:5000 (Molecular Probes) in blocking solution for $10 \mathrm{~min}$ at room temperature. The samples were mounted using an antiphotobleaching medium containing $20 \mathrm{mM} n$-propyl-gallate (Sigma) in $80 \%$ glycerol $/ 20 \%$ PBS and then observed under a microscope equipped with phase contrast and epifluorescence light paths (Leica DMIRE2, Heidelberg, Germany). For confocal imaging, a Zeiss confocal microscope LSM 510 (Zeiss, Göttingen, Germany) was used for data acquisition.

\section{Quantitative real-time PCR}

Total RNA was extracted from pancreatic tissue or cultured cells using Trizol reagent (Invitrogen) and was treated with DNase (Invitrogen). RNA (500 ng) was reverse transcribed to cDNA in a $25 \mu \mathrm{l}$ solution containing $5 \mu \mathrm{l} 5 \mathrm{x}$ first strand buffer (Invitrogen), $10 \mathrm{mmol} / 1$ dithiothreitol (Invitrogen), $1 \mathrm{mmol} / \mathrm{l} \mathrm{dNTPs}$ (New England Biolabs, Ipswich, MA, USA), 
$50 \mathrm{ng}$ random hexamers (Invitrogen), and 200 units Superscript II Rnase $\mathrm{H}$ reverse transcriptase (Invitrogen). Reverse transcription reactions were incubated for $10 \mathrm{~min}$ at $25^{\circ} \mathrm{C}$, $60 \mathrm{~min}$ at $42^{\circ} \mathrm{C}$, and $10 \mathrm{~min}$ at $95^{\circ} \mathrm{C}$. PCR analyses were carried out in duplicate using $1 / 10$ th of the cDNA per reaction and $400 \mathrm{nmol} / \mathrm{l}$ forward and reverse primers with Smart Quant Green Master Mix (Protech Technology Enterprise, Taipei, Taiwan). The expression of human glyceraldehyde-3-phosphate dehydrogenase $(G A P D H)$ was used as a housekeeping gene for normalization of gene expression levels. The following primer pair sequences (with accession numbers and product sizes) were used in this study: Nestin (NM_006617, 131 bp) F: 5'-CTGCGGGCTACTGAAAAGTT- $3^{\prime}$ and R: 5'-AGGCTGAGGGACATCTTGAG-3'; neurogenin 3 (NGN3, NM_020999, 293 bp) F: $5^{\prime}$-TGCGCCGGTAGAAAGGATGAC- $3^{\prime}$ and R: $5^{\prime}$-GCTCGCGGTCGTTGGCCTTCTTTC-3'; Paired box gene 6 (PAX6, NM_001604, 303 bp) F: 5'-GAATCAGAGAAGACAGGCCA- $3^{\prime}$ and R: $5^{\prime}$-GTGTAGGTATCATAACTCCG-3'; NeuroD (NM_002500, 384 bp) F: 5'-AAGAACTACATCTGGGCTCTGTCG-3' and R: $5^{\prime}$-GCTGAGGGGTCCATCAAAGG-3'; PDX1 (NM_000209，139 bp) F: $5^{\prime}$-GGAGCCGGAGGAGAACAAG- $3^{\prime}$ and R: $5^{\prime}$-CTCGGTCAAGTTCAACATGACAG- $3^{\prime}$; glucose transporter 2 (GLUT2, NM_000340, 211 bp) F: 5'-GGTTTGTAACTTATGCCTAAG-3' and R: 5'-GCCTAGTTATGCATGCAG-3'; Insulin (NM_000207, 115 bp) F: 5'-ACCAGCATCTGCTCCCTCTA-3' and R: 5'-GGTTCAAGGGCTTTATTCCA-3'; and GAPDH (NM_002046, 372 bp) F: $5^{\prime}$-CACCATCTTCCAGGAGCGAG-3' and R: 5'-TCACGCCACAGTTTCCCGGA-3'. Real-time PCR was performed using the ABI 7500 System (Applied Biosystems, Foster City, CA, USA) with the following cycling program: $50{ }^{\circ} \mathrm{C}$ for $2 \mathrm{~min}, 95^{\circ} \mathrm{C}$ for $10 \mathrm{~min}$, and 35 cycles at $95^{\circ} \mathrm{C}$ for $15 \mathrm{~s}$ and $60^{\circ} \mathrm{C}$ for $1 \mathrm{~min}$. Melting curves were obtained at $60{ }^{\circ} \mathrm{C}$. The number of PCR cycles was titrated in order to remain in the linear range of amplification. The resultant amplification products $(10 \mu \mathrm{l})$ were separated using $2 \%$ agarose gel electrophoresis and were visualized with ethidium bromide that validated the specificity of the real-time PCRs. The data were analyzed using the $2^{-\Delta \Delta C_{\mathrm{t}}}$ method (Livak \& Schmittgen 2001). Gene expression in the insulin-producing cell cultures at various stages (expansion, differentiation, and maturation) was expressed relative to that observed in the insulin-producing cell of the pancreatic tissue stage.

\section{Insulin and DNA content}

The cells were washed twice with PBS, resuspended in $300 \mu \mathrm{l}$ of distilled cold water, and homogenized by sonication on ice. An aliquot of the homogenates was analyzed fluorometerically for DNA content in duplicate, and another aliquot was extracted with acid ethanol overnight and measured for insulin content using an ELISA kit (Mercodia, Uppsala, Sweden).

\section{Glucose challenge test}

Islet-like cell clusters in the maturation phase were washed three times with assay buffer $(111 \mathrm{mmol} / 1 \mathrm{NaCl}, 27 \mathrm{mmol} / \mathrm{l}$ $\mathrm{NaHCO}_{3}, 5 \mathrm{mmol} / \mathrm{K} \mathrm{KCl}, 1 \mathrm{mmol} / 1 \mathrm{CaCl}_{2}, 1 \mathrm{mmol} / \mathrm{l}$ $\mathrm{MgCl}_{2}, 0.3 \mathrm{mmol} / 1 \quad \mathrm{MgSO}_{4}, 1 \cdot 18 \mathrm{mmol} / 1 \mathrm{Na}_{2} \mathrm{HPO}_{4}$, $0 \cdot 29 \mathrm{mmol} / 1 \mathrm{KH}_{2} \mathrm{PO}_{4}, 0 \cdot 2 \% \mathrm{BSA}$, and $2 \cdot 8 \mathrm{mmol} / 1$ glucose) after which they were incubated for $30 \mathrm{~min}$ in $5.6 \mathrm{mmol} / \mathrm{l}$ glucose. Fresh assay buffer $(500 \mu \mathrm{l})$ containing either $25 \mathrm{mmol} / 1$ glucose or additional $\mathrm{KCl}(30 \mathrm{mmol} / \mathrm{l})$ was added, and the cells were incubated for an additional $30 \mathrm{~min}$ at $37^{\circ} \mathrm{C}$. Following the incubation, $300 \mu \mathrm{l}$ of the assay buffer was collected, and C-peptide concentrations were measured using an ELISA assay kit as follows.

\section{C-peptide secretion}

For analysis of C-peptide secretion, medium recovered from the glucose challenge test was analyzed using an ELISA kit (Mercodia) according to the manufacturer's instructions. Briefly, using the supplied 96-well plate, $25 \mu \mathrm{l}$ of sample was added to each well containing $50 \mu \mathrm{l}$ assay buffer and incubated for $1 \mathrm{~h}$ at $18-25^{\circ} \mathrm{C}$ on a shaker. After washing six times with wash buffer (0.5\% Tween 20 in PBS), $100 \mu$ l enzyme conjugate was dispensed into each well, and then incubated at $18-25^{\circ} \mathrm{C}$ on a shaker. After a final wash, $200 \mu \mathrm{l}$ tetramethylbenzidine substrate was added to each well and incubated for $15 \mathrm{~min}$ after which $50 \mu \mathrm{l}$ stop solution was added quickly to the wells. The optical density was determined using $\mathrm{A}^{450}$ wavelength light in an Automated Immuno and Chemical Analyzer (ChemWell, Taipei, Taiwan).

Intrahepatic islet-like cell injection in STZ-induced diabetic rats

Twenty-five male Sprague-Dawley rats maintained as a closed colony (body weight 180-200 g) were used in this study.

Table 2 Average yield of insulin-producing cells and clusters at each phase of pancreatic endocrine precursor cell culture. Data are shown as mean \pm s.D.

\begin{tabular}{|c|c|c|c|c|c|}
\hline & $\begin{array}{l}\text { Pancreatic } \\
\text { tissue }\left(\times 10^{7} / \mathrm{g}\right)\end{array}$ & $\begin{array}{l}\text { Endocrine } \\
\text { precursors }\left(\times 10^{4}\right)\end{array}$ & $\begin{array}{l}\text { Expansion } \\
\text { phase }\left(\times 10^{6}\right)\end{array}$ & $\begin{array}{l}\text { Differentiation } \\
\text { phase }\left(\times 10^{6}\right)\end{array}$ & $\begin{array}{l}\text { Maturation } \\
\text { phase }\left(\times 10^{6}\right)\end{array}$ \\
\hline Cell number & $2 \cdot 49(0 \cdot 27)$ & $1 \cdot 28(0 \cdot 21)$ & $3 \cdot 58(0 \cdot 25)$ & $2 \cdot 98(0 \cdot 23)$ & $3 \cdot 21(0 \cdot 20)$ \\
\hline Islet-like cell cluster (>50 m) & $228(45)$ & ND & ND & $2467(151)$ & $3148(383)$ \\
\hline
\end{tabular}

ND, not determined. 

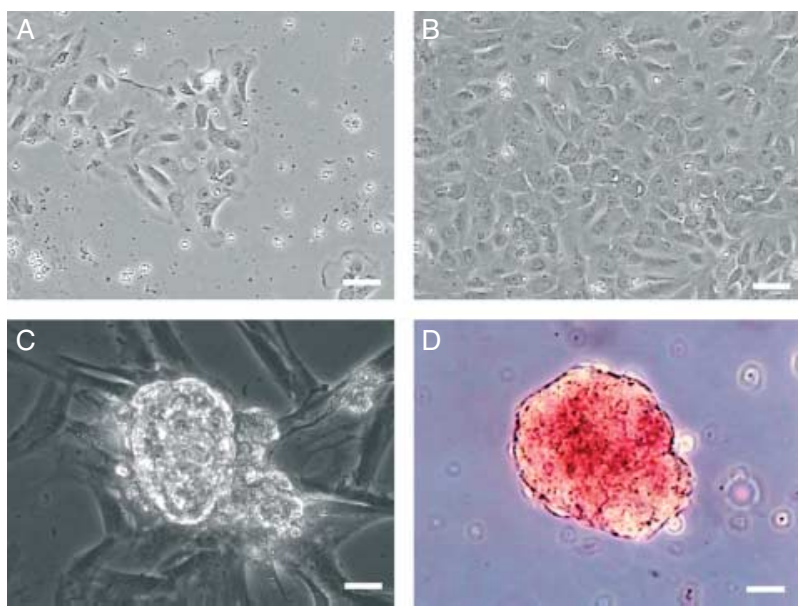

Figure 1 Morphological analysis of cultured human pancreatic insulin-producing cells. (A) Phase contrast microscopy of isolated pancreatic cells shows a round shape with a large nucleus and abundant cytoplasm and some spindle-shaped cells. (B) In the expansion phase, isolated pancreatic stem cells grew rapidly in conditioned culture medium. (C) Upon culture in serum-free medium with Matrigel (the differentiation phase), some cells formed network structures. (D) In the maturation phase, dithizone staining was used to detect zinc-containing islet cell clusters by light microscopy. Bar $=60 \mu \mathrm{m}$ (A and B). Bar $=20 \mu \mathrm{m}$ (C and D).

The experiment was performed with the approval of the Laboratory Animal Center of the National Defense Medical Center in Taipei, Taiwan. Hyperglycemia was induced in 16 rats through i.p. injection of $60 \mathrm{mg} / \mathrm{kg} \mathrm{STZ}$. Blood glucose levels were determined using the Roche ACCU-CHEK glucose meter (Roche Diagnositics) and blood isolated from the tail vein. Stable hyperglycemia (defined as blood glucose levels ranging from $16 \cdot 7$ to $33.3 \mathrm{mmol} / \mathrm{l}$ ) developed in 14 rats after 1 week. Nonfasted, recipient diabetic rats were anesthetized with pentobarbital (40 mg/kg, i.p.), and implantation of an indwelling vascular catheter was performed as previously described (Strubbe \& Steffens 1977). Briefly, after midline laparotomy, a small s.c. pocket in the left groin was created for placement of the vascular access device (Port-A catheter), which was filled with heparinized saline $(10 \mathrm{U} / \mathrm{ml})$. The catheter, connected to the Port-A, was s.c. inserted into the peritoneal cavity through a small puncture in the anterior abdominal wall. The free end of the catheter was then placed into the gastroduodenal vein, at the junction with the portal vein. For islet infusion, the Port-A was percutaneously punctured with a 21 gauge needle. After injecting $1 \mathrm{ml}$ heparinized saline, aliquots of $5 \times 10^{6}$ insulin-producing cells or an equal volume of physiological saline were transplanted into the liver according to the study protocol. Blood glucose levels were monitored under nonfasting condition every 2 days after transplantation for a total of 63 days. To measure the human C-peptide, blood samples were analyzed using an ultrasensitive human C-peptide ELISA kit (Mercodia).

\section{Immunohistochemistry}

The rats were killed 9 weeks after transplantation and perfused with $4 \%$ formaldehyde (Ferak, Berlin, Germany). The livers were dissected and cut into $0 \cdot 5-1 \cdot 0 \mathrm{~cm}^{3}$ sections. The samples were dehydrated and embedded in OCT (Sakura Finetek USA, Inc., Torrance, CA, USA) in liquid nitrogen. The cryosections $(5 \mu \mathrm{m})$ were washed twice with PBS and incubated overnight at $4{ }^{\circ} \mathrm{C}$ with mouse anti-human nuclei (1:400; Chemicon) and rabbit anti-human C-peptide (1:100; Santa Cruz Biotechnology, Santa Cruz, CA, USA) antibodies. After three washes with PBS, slides were incubated for $1 \mathrm{~h}$ at room temperature with FITClabeled goat anti-mouse $\operatorname{IgG}(1: 200$; Chemicon) and rhodamine-conjugated goat anti-rabbit IgG (1:500; Chemicon) antibodies. The sections were mounted with mounting medium (Vector Laboratories, Burlingame, CA, USA) and viewed with a fluorescence microscope using appropriate filters.

\section{Statistical analysis}

Statistical analyses were performed using SPSS 15.0 statistics software (SPSS, Inc., Chicago, IL, USA). Donor age and yield of insulin-producing cell data are shown as mean \pm s.D. and $n(\%)$ for categorical variables. The Pearson $\chi^{2}$ test was performed to compare the success rate of insulin-producing cell culture relative to donor characteristics. In addition, Fisher's exact test was performed if any one cell number was less than five. Furthermore, one-way ANOVA was used to compare the measurements for greater than three conditions.

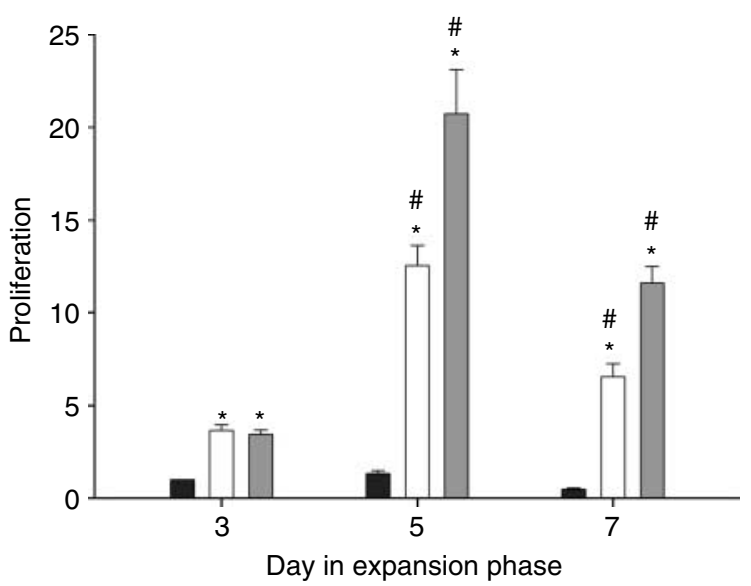

Figure 2 Endocrine precursor cell proliferation assay. Proliferation is expressed relative to absorbance of cells not treated with serum or growth factor on day 3. No serum or growth factor, black bars; serum addition, white bars; serum and growth factor addition, gray bars. Data represent the means \pm S.E.M. of six separate experiments with cells from different donors. $* P<0 \cdot 001$ versus cells not treated with serum and growth factor. ${ }^{\sharp} P<0 \cdot 001$ versus cells on day 3 . 
A repeated ANOVA was also performed to identify differences in glucose changes among the treatment groups. The Bonferroni adjustment was performed for pair-wise comparisons after ANOVA. For most analyses, a $P$ value $<0.05$ was considered statistically significant; an adjusted significance level of $0 \cdot 0167(0 \cdot 05 / 3)$ was used for the Bonferroni test.

\section{Results}

Effects of clinical variables on insulin-producing cell culture success

To determine donor characteristics that may influence culture success, success of insulin-producing cell generation for each characteristic was determined. As shown in Table 1, the overall culture success rate was $35 \%$ for this donor group. Neither donor age nor gender was significantly associated with culture success. Parenchyma consistency was also analyzed; normal pancreatic tissue has soft parenchyma, which by definition is without fibrotic change; hard pancreatic tissue contains fibrotic changes as determined by pathological examination (Haber et al. 1999). Significant differences were observed in culture success and parenchyma consistency; the success rate in insulin-producing cell culture was significantly higher in tissue with soft parenchyma as compared to hard $(48 \cdot 6$ vs $13 \cdot 6 \%$ respectively, $P=0 \cdot 010)$. Furthermore, the primary-type lesion was not significantly associated with insulin-producing cell generation. Thus, pancreatic parenchyma consistency was the only donor characteristic associated with culture success.

\section{Generation of islet-like clusters from adult human pancreas}

To increase the efficiency of insulin-producing cell generation, our culture procedure was developed by modifying the previous methods. The average yield of insulin-producing cell clusters isolated at each culture phase (pancreatic tissue, endocrine precursors, expansion phase, differentiation phase, and maturation phase) was determined using phase contrast micromicroscopy (Table 2). There was no difference in the amount of insulin-producing cells generated from patients undergoing pancreatic head cancer resection versus duodenal cancer resection (data not shown).
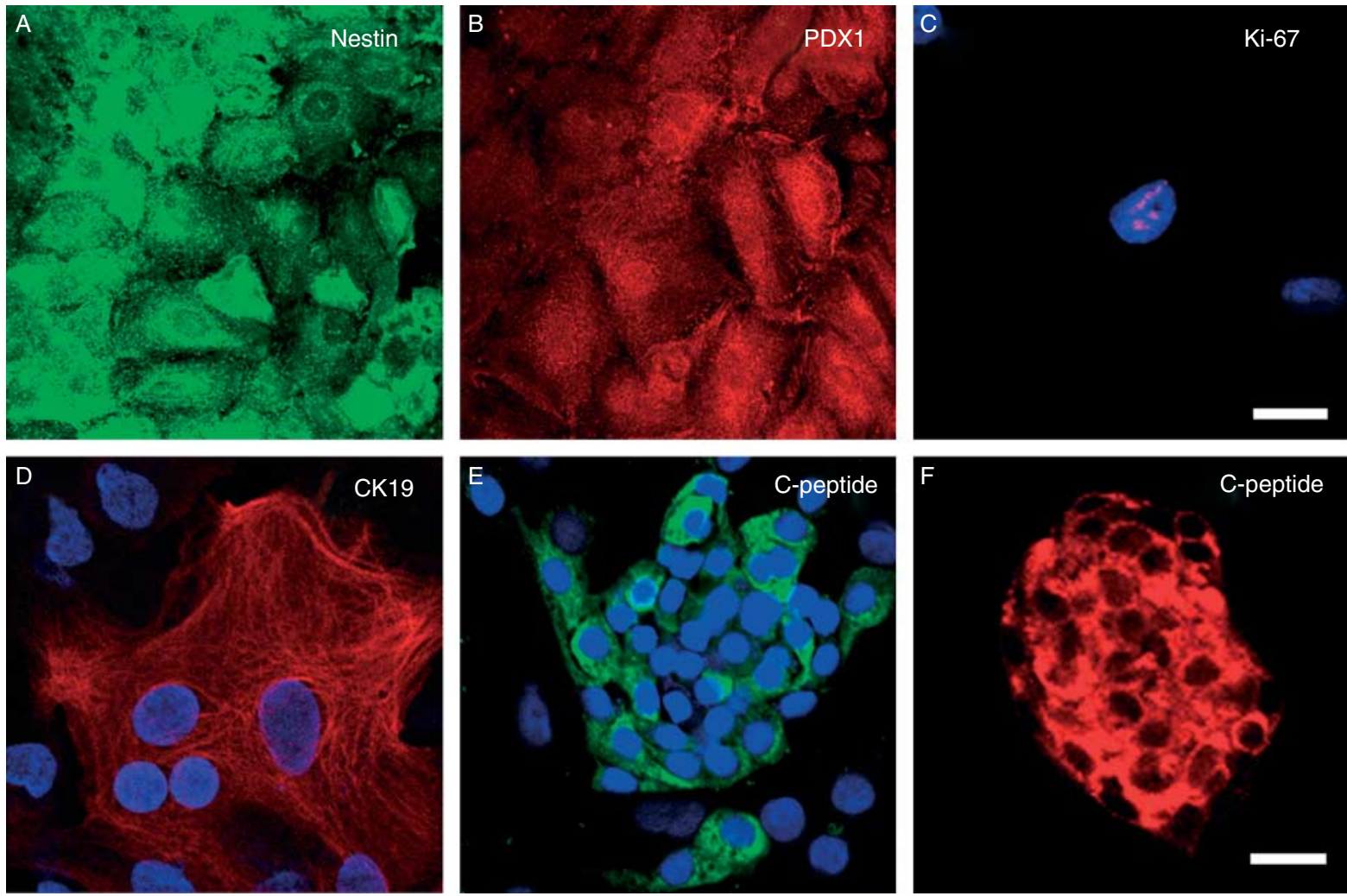

Figure 3 Immunofluorescent analysis of protein expression in insulin-producing cells cultured in the expansion and maturation phases. Confocal microscopy was used to analyze the expression of pancreatic markers. (A and B) Cells in expansion phase were labeled with anti-Nestin (green) and anti-PDX1 (red) primary antibodies. Cultured pancreatic cells were double labeled with (C) antiKi-67 antibody (red) and TOTO-3 nuclear stain (blue) or (D) anti-CK19 antibody (red) and TOTO-3 nuclear stain (blue). Cultured pancreatic cells in the expansion phase $(\mathrm{E})$ and within islet-like cell cluster $(\mathrm{F})$ in the maturation phase were labeled with anti-Cpeptide antibody (green). Bar $=20 \mu \mathrm{m}$. 
In addition to tracking cell and cluster numbers, cell morphology was analyzed throughout the culture period (Fig. 1). Upon culture initiation, the cells began to proliferate and form small colonies (Fig. 1A). After 10-14 days, the cells reached confluence (Fig. 1B). In the expansion period, a 280 -fold increase in cell number was estimated during this period (Table 2). As determined by a proliferation assay, a significant increase in cell growth was observed at days 5 and 7 in the expansion phase (Fig. 2). During the differentiation phase, which extended from 5 to 7 days, both spindle-shaped cells and islet-like cluster formation were observed (Fig. 1C). Finally, in the maturation phase, which lasted 5 days, a red color was observed within the cell clusters upon staining with dithizone, indicating the presence of zinc-containing islet cells (Fig. 1D). The maturation phase increased both the number and size of cell clusters (Table 2).

Cell marker expression in cultured insulin-producing cells within the expansion and maturation phases

To characterize the cultured cells at both the expansion and maturation phases, immunofluorescent staining with confocal microscopy was employed. Most cells cultured in the expansion phase were immunopositive for both nestin (Fig. 3A) and PDX1 (Fig. 3B), which are the markers for pancreatic endocrine stem cells. Although cell numbers increased in the expansion phase (Table 2$)$, few $(<5 \%)$ were immunopositive for Ki-67 (Fig. 3C), a proliferation marker. Compared with the cells in the expansion phase, final harvested cellular insulin/DNA ratio increased by 40-fold in the differentiation and maturation phases (Fig. 4). In addition, the majority of cells $(>80 \%)$ were immunopositive for CK19, suggesting that they were of pancreatic duct cell origin (Fig. 3D). Approximately 5-10\% of the cells in the expansion phase were immunopositive for C-peptide (Fig. 3E); C-peptide expression was also observed in cell clusters within the maturation phase (Fig. 3F).

\section{Islet-like cell clusters expressed genes characteristic of stem and mature pancreatic cells}

The phenotype of cultured pancreatic cells was analyzed by quantitative real-time PCR (Fig. 5). The expression of nestin, a neural stem cell marker, was detected in both surgically resected pancreatic tissue (pancreatic cells) and cells in the expansion phase of culture. The expression of nestin decreased considerably in the differentiation phase and was barely detectable by the maturation phase. During differentiation and maturation, the expression of the transcription factor, NGN3, which is transiently expressed in endocrinespecific precursor cells, was observed; NGN3 expression was also detected within the pancreatic cells (Rajagopal et al. 2003). In the expansion phase, the level of insulin mRNA in the cultured cells had markedly decreased compared to the starting material; however, in the differentiation and maturation phases, upregulation of insulin gene expression

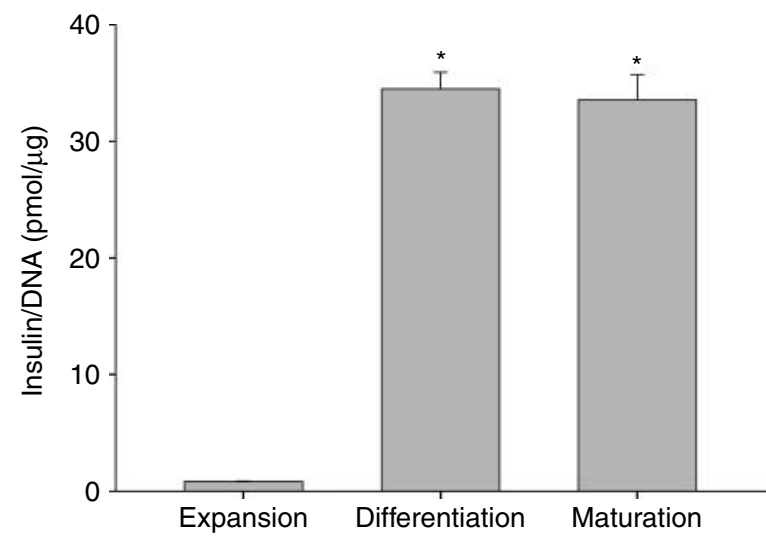

Figure 4 Insulin-to-DNA ratio in the three different phases of cell culture. Data are the means + S.E.M. of five separate experiments with cells from different donors. ${ }^{*} P<0 \cdot 01$.

(up to sixfold) was observed in the majority of cultures. In successful cultures that expressed high levels of insulin, the expression levels of NEUROD, PDX1, and GLUT2 were upregulated in the differentiation and maturation phases as compared to the expansion phase. Furthermore, PAX6 expression also decreased in the expansion phase as compared to the pancreatic cells and increased in the differentiation and maturation phases of culture. Thus, cells within the maturation phase expressed genes associated with mature pancreatic cells to a similar degree as surgically resected pancreatic tissue.

\section{Secretion of C-peptide by insulin-producing cells upon glucose stimulation}

To test whether cell clusters within the maturation phase generated in vitro showed functional characteristics of pancreatic islets, the release of C-peptide was examined (Fig. 6). Because the cells were cultured in media supplemented with insulin, C-peptide was chosen instead of insulin to measure islet function (Hansson et al. 2004). Insulin-producing cells were stimulated with 5.6 or $25 \mathrm{mM}$ glucose or $25 \mathrm{mM}$ glucose $+\mathrm{KCl}$ after which C-peptide secretion was measured. As compared to insulin-producing cells stimulated with $5.6 \mathrm{mM}$ glucose, those receiving $25 \mathrm{mM}$ glucose or $25 \mathrm{mM}$ glucose $+\mathrm{KCl}$ secreted significantly higher levels of C-peptide $(1.68$ vs 101.71 and $86.54 \mathrm{pmol} / \mathrm{DNA}$ per $30 \mathrm{~min}$ respectively; $P<0 \cdot 001$ ). Thus, the insulinproducing cells displayed characteristics associated with pancreatic islet function.

\section{Insulin-producing cells reduced hyperglycemia after transplantation into the diabetic rat model}

To better characterize the functional properties of the insulin-producing cells, they were transplanted into the liver of STZ-induced diabetic rats, and secretion of insulin in 

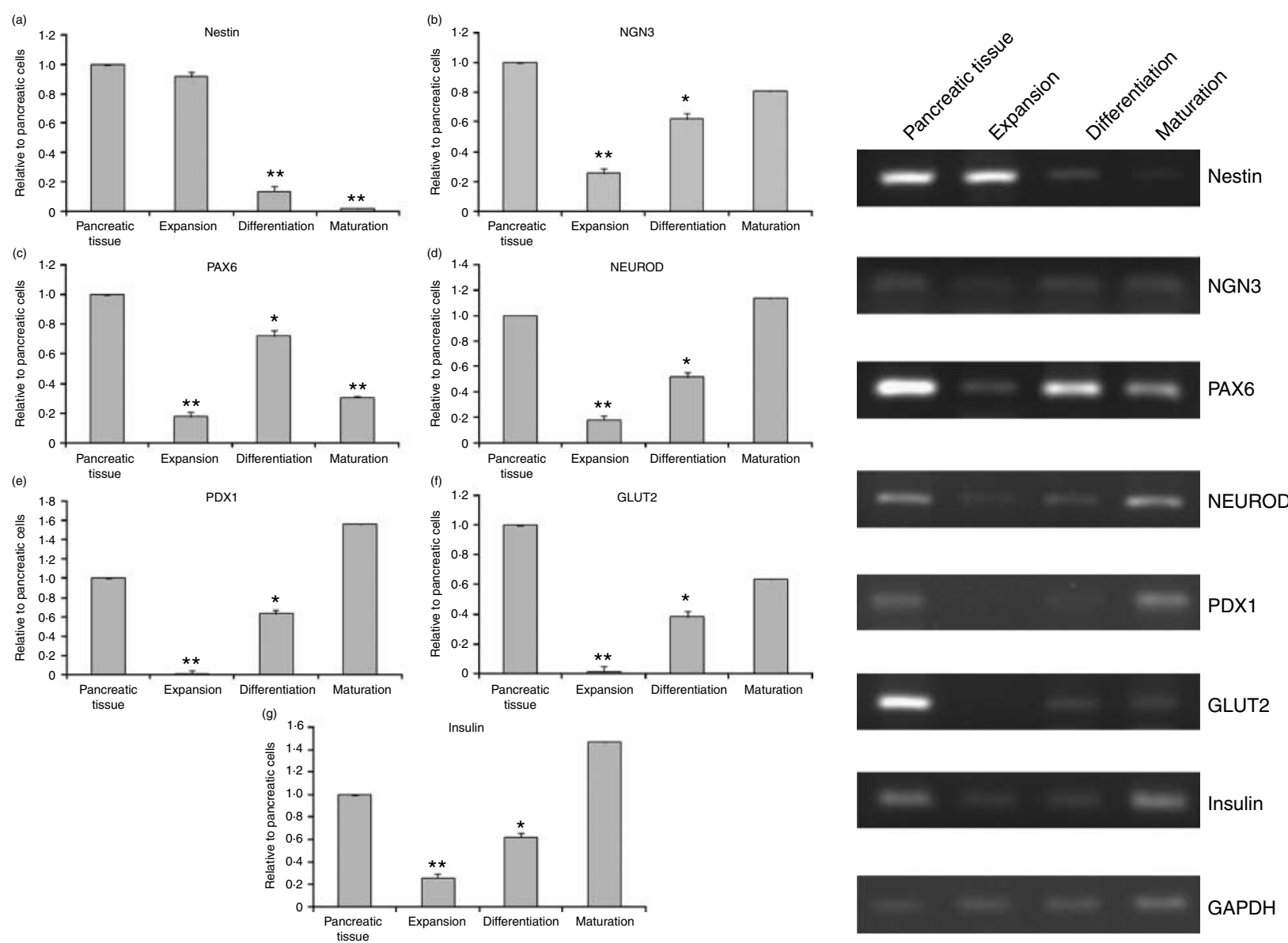

Figure 5 The cultured insulin-producing cells expressed a wide range of pancreatic-, neural-, and stem cell-specific genes: nestin (a), NGN3 (b), PAX6 (c), NEUROD (d), PDX1 (e), GLUT2 (f) and insulin (g). Total RNA was isolated from surgically resected pancreatic tissue as well as cultured cells in the expansion, differentiation, and maturation phases. The RNAs were analyzed using quantitative real-time PCR. GAPDH was used as an internal control for normalization. Gene expression in the insulin-producing cell cultures at various stages was expressed relative to that observed in the insulin-producing cell cultures of pancreatic tissue stage. Similar results were obtained in at least three independent experiments. ${ }^{*} P<0 \cdot 01$ versus pancreatic cells. ${ }^{* *} P<0 \cdot 001$ versus pancreatic cells.

response to high glucose was examined. Hyperglycemia was observed in the untreated STZ-induced diabetic rats as compared to the control group $(P<0 \cdot 001)$. Significant reductions $(30-40 \%, P<0 \cdot 001)$ in blood glucose levels were observed in rats that received insulin-producing cell transplantation as compared to untreated STZ-induced rats (Fig. 7A). Specifically, after week 3, reduced glucose levels were detected in the transplant group as compared to the untreated STZ group. The average survival time was $63,52 \cdot 3$, and 63 days in the control, STZ, and STZ+insulinproducing cell groups respectively.

To demonstrate that the glucose responses shown in Fig. 7A were associated with insulin-producing cell transplantation, human C-peptide levels were measured in the sera of each group (Fig. 7B). The levels of human C-peptide were highest in the STZ + insulin-producing cell group $(P<0 \cdot 0167)$; human $\mathrm{C}$-peptide levels were undetectable in the control and STZ groups. Furthermore, human
C-peptide-positive cells were detected within the liver tissue of the STZ+insulin-producing cell group 9 weeks following islet transplantation (Fig. 8A). Specifically, at least ten $\mathrm{C}$-peptide-positive cell aggregates were detected in the liver of each animal transplanted with insulin-producing cells; human C-peptide-positive cells were absent in the control and untreated STZ rats. The presence of human nuclei confirmed the presence of human cells within the rat liver (Fig. 8B). These results indicate that the transplanted insulinproducing cells are not only functional but also capable of long-term survival upon transplantation.

\section{Discussion}

In this study, functional insulin-producing cells were generated from surgically resected adult human pancreatic tissue. To our knowledge, this is the first study reporting 


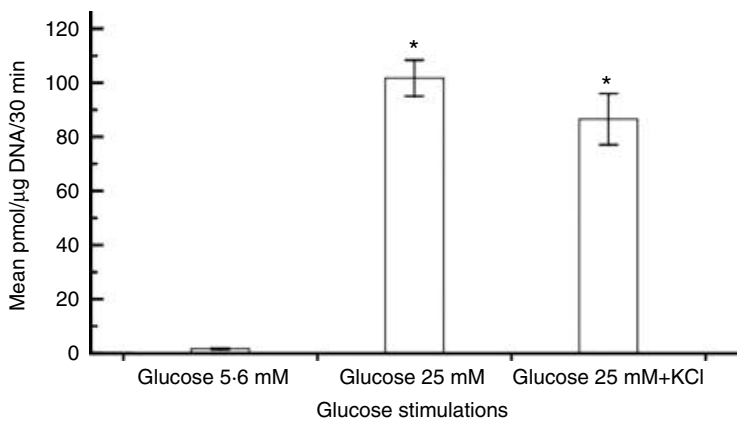

Figure 6 Secretion of C-peptide by cultured human pancreas insulin-producing cells in response to glucose stimulation. Insulinproducing cells cultured in the maturation phase were stimulated as indicated, and C-peptide in the medium was analyzed using ELISA. Measurements were normalized for the DNA content of each sample. Three samples per condition were measured. Similar results were obtained in at least three independent experiments.

${ }^{*} P<0 \cdot 001$ compared to low-glucose stimulation.

the generation of functional insulin-producing cells from this donor source. In addition, culture success was compared with donor characteristics. While not all cultures were successful, the insulin-producing cells expressed NGN3, insulin, PDX1, PAX6, and NEUROD, and GLUT2. In addition, glucosestimulated C-peptide release was significantly increased in the insulin-producing cells. Furthermore, transplantation of insulin-producing cells reduced hyperglycemia in STZ-induced diabetic rats.

Few studies have determined the factors associated with culture outcomes of insulin-producing cells isolated from different human subjects. In this study, insulin-producing cell culture success was not affected by donor age ( $<65$ vs $>65$ years) or gender, which is inconsistent with the previous report (Ihm et al. 2006). Using human islets from cadaveric donors, Ihm et al. (2006) reported that islet preparations from younger donors ( $<40$ years) may improve the success rate of single-donor transplantation. Differences in success rate were observed in insulin-producing cell cultures from pancreatic tissue with soft versus hard parenchyma. It is possible that progenitor cells were more difficult to obtain from pancreatic tissue with hard parenchyma due to the high fibrotic tissue content, which is consistent with Mitnala et al. (2010).

The generation of enough functional islets represents an important step in regeneration therapy for diabetic patients. Previous studies have generated functional islets from islet cells themselves (Gershengorn et al. 2004, Russ et al. 2008, 2009, Joglekar et al. 2009a,b) as well as exocrine and duct cells from adult human pancreas (Bonner-Weir et al. 2000, Todorov et al. 2006) from either cadavers or living organ donors. Indeed, bone marrow stem cells can also be subcultured in vitro to more passages, but reduced levels of functional cells were obtained (Wu et al. 2009).

Despite the enormous efforts directed at understanding the factors that control growth and development of $\beta$-cells, the existence of adult pancreatic stem or progenitor cells for $\beta$-cell replacement in patients with diabetes remains unknown (Levine \& Mercola 2004, Hao et al. 2006). Because islets comprise $<2 \%$ of cells within the adult human pancreas (Bouwens \& Rooman 2005), whole pancreatic tissue instead of islets alone was used as the starting material. Surgically resected pancreatic tissue consists of endocrine cells as well as interstitial and adherent exocrine acinar and ductal cells, blood vessels, stroma, and potentially yet unknown stem cells. We reasoned if resected pancreatic tissue contained endocrine progenitors, the amount of insulin-producing cells available for transplantation may be increased. Approximately 3000 islet-like cell clusters were generated from $1 \mathrm{~g}$ of pancreatic tissue. Because only 0 $\cdot 5-2 \mathrm{~g}$ pancreatic tissue were used as the starting material in this study, the scale of insulin-producing cell cultures could be readily expanded to meet the needs of transplantation in a clinical setting.

The expression of NGN3 during the differentiation phase supports the occurrence of endocrine cell neogenesis, as NGN3 is essential for the development of the endocrine cell lineages in the pancreas during embryogenesis (Gradwohl et al. 2000). In this study, NGN3 was detected in freshly isolated adult human pancreatic tissue. Thus, the presence of NGN3 could reflect ongoing endocrine cell neogenesis in
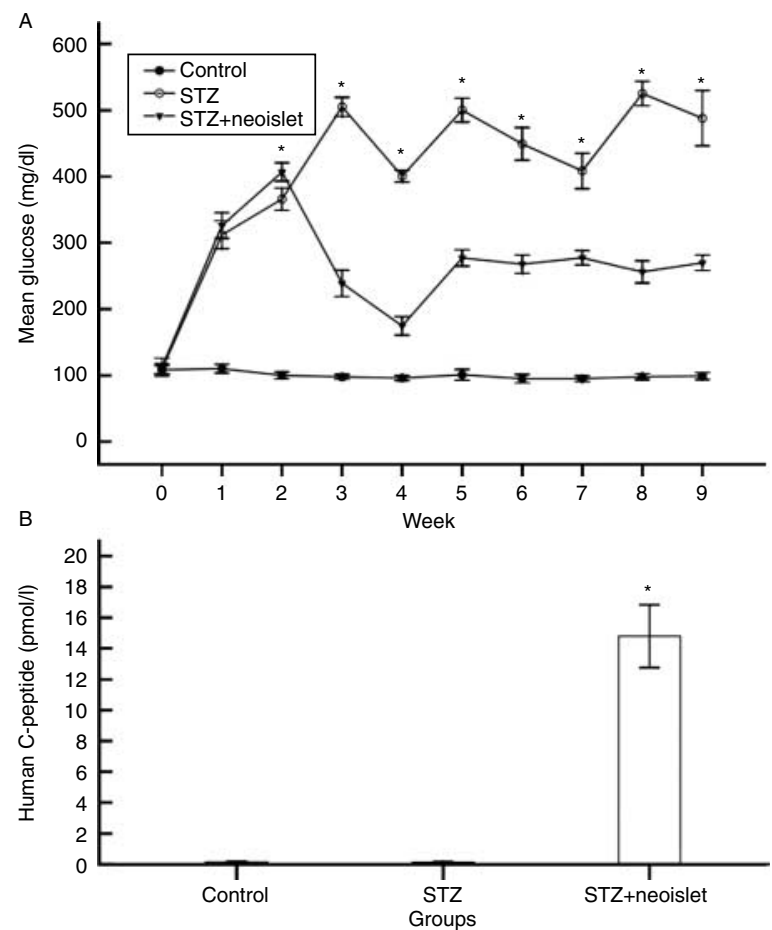

Figure 7 Cultured human pancreas insulin-producing cells reduced hyperglycemia after transplantation into streptozotocin-induced diabetic rats. (A) Cultured insulin-producing cells or PBS were transplanted into the portal vein of streptozotocin-induced diabetic rats (STZ+insulin-producing cell and STZ groups respectively). Control (closed circle), STZ (open circle), and STZ+ insulinproducing cell (filled down triangle). (B) Human C-peptide levels in the sera of control, STZ, and STZ+insulin-producing cell groups. Day 0 indicates the day of cell transplantation. ${ }^{*} P<0 \cdot 01$. 

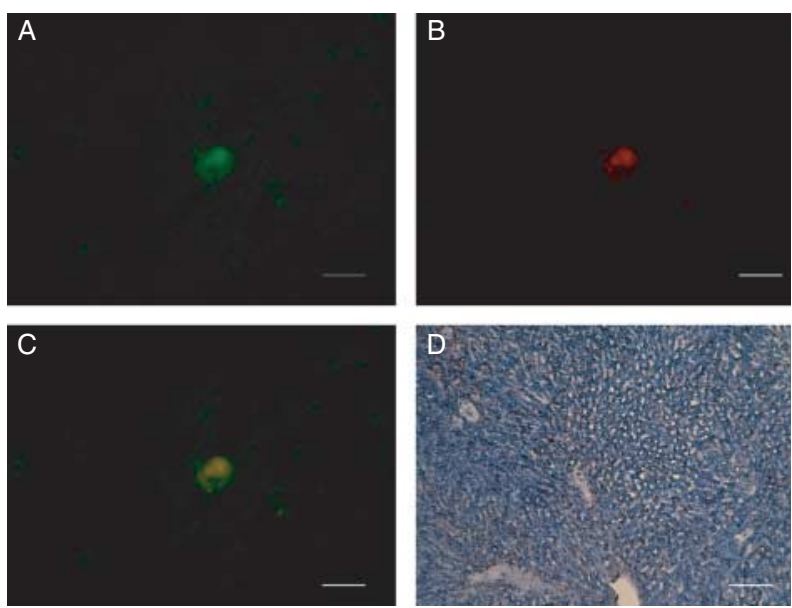

Figure 8 Expression of human C-peptide within the liver of STZ-induced diabetic rats after insulin-producing cell transplantation. Nine weeks after insulin-producing cell transplantation, the livers of streptozocin-induced diabetic rats were analyzed. Frozen sections of liver were double-labeled with anti-human C-peptide antibody (A) and anti-human nuclear antibody (B). (C) Merged images from (A and B). (D) Hematoxylin stain of the hepatic tissue. Bar $=100 \mu \mathrm{m}$.

adult islets in vivo or induced neogenesis due to the stress of pancreatic tissue isolation. However, the expression of NGN3 itself does not always support neogenesis mature cells may be dedifferentiated into NGN3-expressing cells (Kodama et al. 2005, Baeyens et al. 2006). Furthermore, a recent study demonstrated the clonal isolation of nestin-positive, endocrine progenitor cells from the adult mouse pancreas (Seaberg et al. 2004). Nestin has been previously suggested as a marker of pancreatic stem/progenitor cells (Lumelsky et al. 2001); however, this issue remains controversial (Selander \& Edlund 2002, Treutelaar et al. 2003, Kushner et al. 2010). Lineage tracing studies found no contribution of stem/progenitor cells to $\beta$-cell renewal in adult mice, questioning the role of such cells in vivo (Gershengorn et al. 2004, Russ et al. 2008, 2009, Joglekar et al. 2009a,b). Other reports have indicated that CK19-expressing cells, believed to be of ductal origin, are the in vitro and in vivo precursors of $\beta$-cells (Gao et al. 2003, Hao et al. 2006). Lineage tracing studies of pancreatic ductal cells revealed that they are the in vivo progenitor, producing new islets after injury (Bonner-Weir et al. 2008). However, Solar et al. (2009) reported no such contribution of pancreatic ductal epithelium in postnatal endocrine or acinar cell development. In this study, expansion cultures consisted of nestin- as well as CK19-expressing cells, but the lineage relationships between these cell types and endocrine cells remain to be determined.

The dedifferentiation of pancreatic $\beta$-cells during in vitro expansion represents a major problem in using cultured cells for transplantation (Beattie et al. 1999). Maintenance of islet architecture by expansion in a three-dimensional gel matrix may limit this problem (Beattie et al. 2002). In this study, formation of three-dimensional cell clusters along with growth arrest in serum-free medium may be a critical factor for successful endocrine differentiation. Dedifferentiation and redifferentiation of cells in vitro have also been observed in other systems, including neural (Kondo \& Raff 2000) and skin progenitor cells (Li et al. 2004). Further studies are required to differentiate between $\beta$-cell dedifferentiation/redifferentiation and the presence of preexisting stem/progenitor cells in the adult pancreas. However, from a therapeutic point of view, any approach that generates more $\beta$-cells for transplantation is important.

This study has limitations that should be considered. The surgically resected donor pancreatic tissues were isolated from patients with various pancreatic diseases. However, normal tissue within the donor tissue was pathologically identified and used for subsequent insulin-producing cell culture generation. Functional islets were generated from 35\% of the donor tissue. Thus, the identification of a new source of tissue from which to generate neoislets is beneficial for the overall field of transplantation therapy (Wang et al. 2010). In addition, the precise feature of the culture procedure associated with neoislet proliferation and differentiation was not assessed in this study. For example, use of mixed cell cultures with a three-dimensional structure may have increased neoislet proliferation and differentiation. In addition, supplementation of the culture medium with NGF, EGF, and nicotinamide was essential to induce the proliferation of endocrine precursors. Furthermore, use of bFGF, ITS + 1 serum-free medium, and high-glucose culture medium was also important to promote islet differentiation and increase insulin content. Further studies are necessary to determine the association of these factors with proliferation and differentiation of insulin-producing cells.

In conclusion, this study describes the isolation of pancreatic endocrine precursor cells from adult human pancreatic tissue and the redifferentiation of insulin-secreting $\beta$-like cells from in vitro-cultured insulin-producing cell precursors. Further studies to optimize the in vitro differentiation and augmentation of cell proliferation are necessary.

\section{Declaration of interest}

The authors declare that there is no conflict of interest that could be perceived as prejudicing the impartiality of the research reported.

\section{Funding}

This work was funded by grants from the Taipei Veterans General Hospital (V99E1-004) to T-H C, the National Science Council Grant (NSC 95-2314B-075-053-MY3) to Y-M S, and the Medical Research Grant (TSGH-C99011-12-S03) to J-F S.

\section{Acknowledgements}

We thank Hui-Chi Tsung for her expert technical assistance and Dr Chia-Ning Shen for help in preparing the manuscript. 


\section{References}

Atkinson MA 2005 ADA Outstanding Scientific Achievement Lecture 2004. Thirty years of investigating the autoimmune basis for type 1 diabetes: why can't we prevent or reverse this disease? Diabetes 54 1253-1263. (doi:10.2337/diabetes.54.5.1253)

Baeyens L, Bonné S, German MS, Ravassard P, Heimberg H \& Bouwens L 2006 Ngn 3 expression during postnatal in vitro $\beta$ cell neogenesis induced by the JAK/STAT pathway. Cell Death and Differentiation 13 1892-1899. (doi:10.1038/sj.cdd.4401883)

Beattie GM, Itkin-Ansari P, Cirulli V, Leibowitz G, Lopez AD, Bossie S, Mally MI, Levine F \& Hayek A 1999 Sustained proliferation of PDX-1 + cells derived from human islets. Diabetes 48 1013-1019. (doi:10.2337/diabetes. 48.5.1013)

Beattie GM, Montgomery AM, Lopez AD, Hao E, Perez B, Just ML, Lakey JR, Hart ME \& Hayek A 2002 A novel approach to increase human islet cell mass while preserving $\beta$-cell function. Diabetes 51 3435-3439. (doi:10. 2337/diabetes.51.12.3435)

Bonner-Weir S, Taneja M, Weir GC, Tatarkiewicz K, Song KH, Sharma A \& O'Neil JJ 2000 In vitro cultivation of human islets from expanded ductal tissue. PNAS 97 7999-8004. (doi:10.1073/pnas.97.14.7999)

Bonner-Weir S, Inada A, Yatoh S, Li WC, Aye T, Toschi E \& Sharma A 2008 Transdifferentiation of pancreatic ductal cells to endocrine $\beta$-cells. Biochemical Society Transactions 36 353-356. (doi:10.1042/BST0360353)

Bouwens L \& Rooman I 2005 Regulation of pancreatic $\beta$-cell mass. Physiological Reviews 85 1255-1270. (doi:10.1152/physrev.00025.2004)

Dodge R, Loomans C, Sharma A \& Bonner-Weir S 2009 Developmental pathways during in vitro progression of human islet neogenesis. Differentiation 77 135-147. (doi:10.1016/j.diff.2008.09.015)

Gao R, Ustinov J, Pulkkinen MA, Lundin K, Korsgren O \& Otonkoski T 2003 Characterization of endocrine progenitor cells and critical factors for their differentiation in human adult pancreatic cell culture. Diabetes $\mathbf{5 2}$ 2007-2015. (doi:10.2337/diabetes.52.8.2007)

Gershengorn MC, Hardikar AA, Wei C, Geras-Raaka E, Marcus-Samuels B \& Raaka BM 2004 Epithelial-to-mesenchymal transition generates proliferative human islet precursor cells. Science 306 2261-2264. (doi:10. 1126/science.1101968)

Gradwohl G, Dierich A, LeMeur M \& Guillemot F 2000 Neurogenin3 is required for the development of the four endocrine cell lineages of the pancreas. PNAS 97 1607-1611. (doi:10.1073/pnas.97.4.1607)

Haber PS, Keogh GW, Apte MV, Moran CS, Stewart NL, Crawford DH, Pirola RC, McCaughan GW, Ramm GA \& Wilson JS 1999 Activation of pancreatic stellate cells in human and experimental pancreatic fibrosis. American Journal of Pathology 155 1087-1095.

Hansson M, Tonning A, Frandsen U, Petri A, Rajagopal J, Englund MC, Heller RS, Håkansson J, Fleckner J, Sköld HN et al. 2004 Artifactual insulin release from differentiated embryonic stem cells. Diabetes $\mathbf{5 3}$ 2603-2609. (doi:10.2337/diabetes.53.10.2603)

Hao E, Tyrberg B, Itkin-Ansari P, Lakey JR, Geron I, Monosov EZ, Barcova M, Mercola M \& Levine F $2006 \beta$-Cell differentiation from nonendocrine epithelial cells of the adult human pancreas. Nature Medicine 12 310-316. (doi:10.1038/nm1367)

Ihm SH, Matsumoto I, Sawada T, Nakano M, Zhang HJ, Ansite JD, Sutherland DE \& Hering BJ 2006 Effect of donor age on function of isolated human islets. Diabetes 55 1361-1368. (doi:10.2337/db05-1333)

Joglekar MV, Patil D, Joglekar VM, Rao GV, Reddy DN, Mitnala S, Shouche Y \& Hardikar AA 2009a The miR-30 family microRNAs confer epithelial phenotype to human pancreatic cells. Islets 1 137-147. (doi:10.4161/isl.1.2.9578)

Joglekar MV, Joglekar VM, Joglekar SV \& Hardikar AA $2009 b$ Human fetal pancreatic insulin-producing cells proliferate in vitro. Journal of Endocrinology 201 27-36. (doi:10.1677/JOE-08-0497)

Kodama S, Toyonaga T, Kondo T, Matsumoto K, Tsuruzoe K, Kawashima J, Goto H, Kume K, Kume S, Sakakida M et al. 2005 Enhanced expression of PDX- 1 and Ngn 3 by exendin- 4 during $\beta$ cell regeneration in STZ-treated mice. Biochemical and Biophysical Research Communications 327 1170-1178. (doi:10.1016/j.bbrc.2004.12.120)
Kondo T \& Raff M 2000 Oligodendrocyte precursor cells reprogrammed to become multipotential CNS stem cells. Science 289 1754-1757. (doi:10. 1126/science.289.5485.1754)

Kushner JA, Weir GC \& Bonner-Weir S 2010 Ductal origin hypothesis of pancreatic regeneration under attack. Cell Metabolism 11 2-3. (doi:10.1016/ j.cmet.2009.12.005)

Larsen JL 2004 Pancreas transplantation: indications and consequences. Endocrine Reviews 25 919-946. (doi:10.1210/er.2002-0036)

Lechner A \& Habener JF 2003 Stem/progenitor cells derived from adult tissues: potential for the treatment of diabetes mellitus. American Journal of Physiology. Endocrinology and Metabolism 284 E259-E266. (doi:10.1152/ ajpendo.00393.2002)

Lechner A, Nolan AL, Blacken RA \& Habener JF 2005 Redifferentiation of insulin-secreting cells after in vitro expansion of adult human pancreatic islet tissue. Biochemical and Biophysical Research Communications 327 581-588. (doi:10.1016/j.bbrc.2004.12.043)

Levine F \& Mercola M 2004 No pancreatic endocrine stem cells? New England Journal of Medicine 351 1024-1026. (doi:10.1056/ NEJMcibr041779)

Li A, Pouliot N, Redvers R \& Kaur P 2004 Extensive tissue-regenerative capacity of neonatal human keratinocyte stem cells and their progeny. Journal of Clinical Investigation 113 390-400. (doi:10.1172/JCI19140)

Lin HT, Chiou SH, Kao CL, Shyr YM, Hsu CJ, Tarng YW, Ho LL, Kwok CF $\&$ Ku HH 2006 Characterization of pancreatic stem cells derived from adult human pancreas ducts by fluorescence activated cell sorting. World Journal of Gastroenterology 12 4529-4535.

Livak KJ \& Schmittgen TD 2001 Analysis of relative gene expression data using real-time quantitative PCR and the $2(-$ Delta Delta $C(\mathrm{~T}))$ method. Methods 25 402-408. (doi:10.1006/meth.2001.1262)

Lumelsky N, Blondel O, Laeng P, Velasco I, Ravin R \& McKay R 2001 Differentiation of embryonic stem cells to insulin-secreting structures similar to pancreatic islets. Science 292 1389-1394. (doi:10.1126/science.1058866)

Maria-Engler SS, Corrêa-Giannella ML, Labriola L, Krogh K, Colin C, Lojudice FH, Aita CA, de Oliveira EM, Corrêa TC, da Silva IC et al. 2004 Co-localization of nestin and insulin and expression of islet cell markers in long-term human pancreatic nestin-positive cell cultures. Journal of Endocrinology 183 455-467. (doi:10.1677/joe.1.05703)

McNary WF Jr 1954 Zinc-dithizone reaction of pancreatic islets. Journal of Histochemistry and Cytochemistry 2 185-194.

Mitnala S, Pondugala PK, Guduru VR, Rabella P, Thiyyari J, Chivukula S, Boddupalli S, Hardikar AA \& Reddy DN 2010 Reduced expression of PDX-1 is associated with decreased $\beta$ cell function in chronic pancreatitis. Pancreas 39 856-862. (doi:10.1097/MPA.0b013e3181d6bc69)

Moriscot C, de Fraipont F, Richard MJ, Marchand M, Savatier P, Bosco D, Favrot M \& Benhamou PY 2005 Human bone marrow mesenchymal stem cells can express insulin and key transcription factors of the endocrine pancreas developmental pathway upon genetic and/or microenvironmental manipulation in vitro. Stem Cells 23 594-603. (doi:10.1634/stemcells.20040123)

Nerup J, Bendixen G \& Binder C 1970 Autoimmunity in diabetes mellitus. Lancet 296 610-611. (doi:10.1016/S0140-6736(70)90195-9)

Rajagopal J, Anderson WJ, Kume S, Martinez OI \& Melton DA 2003 Insulin staining of ES cell progeny from insulin uptake. Science 299363. (doi:10.1126/science.1077838)

Rapoport DH, Schicktanz S, Gürleyik E, Zühlke C \& Kruse C 2009 Isolation and in vitro cultivation turns cells from exocrine human pancreas into multipotent stem-cells. Annals of Anatomy 191 446-458. (doi:10.1016/ j.anat.2009.07.002)

Russ HA, Bar Y, Ravassard P \& Efrat S 2008 In vitro proliferation of cells derived from adult human $\beta$-cells revealed by cell-lineage tracing. Diabetes 57 1575-1583. (doi:10.2337/db07-1283)

Russ HA, Ravassard P, Kerr-Conte J, Pattou F \& Efrat S 2009 Epithelialmesenchymal transition in cells expanded in vitro from lineage-traced adult human pancreatic $\beta$ cells. PLoS ONE 4 e6417. (doi:10.1371/journal.pone. 0006417)

Ryan EA, Bigam D \& Shapiro AM 2006 Current indications for pancreas or islet transplant. Diabetes, Obesity and Metabolism 8 1-7. (doi:10.1111/j.14631326.2004.00460.x) 
Samson SL \& Chan L 2006 Gene therapy for diabetes: reinventing the islet. Trends in Endocrinology and Metabolism 17 92-100. (doi:10.1016/j.tem.2006. 02.002)

Seaberg RM, Smukler SR, Kieffer TJ, Enikolopov G, Asghar Z, Wheeler MB, Korbutt G \& van der Kooy D 2004 Clonal identification of multipotent precursors from adult mouse pancreas that generate neural and pancreatic lineages. Nature Biotechnology 22 1115-1124. (doi:10.1038/nbt1004)

Selander L \& Edlund H 2002 Nestin is expressed in mesenchymal and not epithelial cells of the developing mouse pancreas. Mechanisms of Development 113 189-192. (doi:10.1016/S0925-4773(02)00023-0)

Shapiro AM, Lakey JR, Ryan EA, Korbutt GS, Toth E, Warnock GL, Kneteman NM \& Rajotte RV 2000 Islet transplantation in seven patients with type 1 diabetes mellitus using a glucocorticoid-free immunosuppressive regimen. New England Journal of Medicine 343 230-238. (doi:10.1056/ NEJM200007273430401)

Shapiro AM, Nanji SA \& Lakey JR 2003 Clinical islet transplant: current and future directions towards tolerance. Immunological Reviews 196 219-236. (doi:10.1046/j.1600-065X.2003.00085.x)

Shapiro AM, Ricordi C, Hering BJ, Auchincloss H, Lindblad R, Robertson RP, Secchi A, Brendel MD, Berney T, Brennan DC et al. 2006 International trial of the Edmonton protocol for islet transplantation. New England Journal of Medicine 355 1318-1330. (doi:10.1056/ NEJMoa061267)

Solar M, Cardalda C, Houbracken I, Martin M, Maestro MA, De Medts N, Xu X, Grau V, Heimberg H, Bouwens L et al. 2009 Pancreatic exocrine duct cells give rise to insulin-producing $\beta$ cells during embryogenesis but not after birth. Developmental Cell 17 849-860. (doi:10.1016/j.devcel.2009. 11.003)

Strubbe JH \& Steffens AB 1977 Blood glucose levels in portal and peripheral circulation and their relation to food intake in the rat. Physiology and Behavior 19 303-307. (doi:10.1016/0031-9384(77)90342-0)

Sung HH, Juang JH, Lin YC, Kuo CH, Hung JT, Chen A, Chang DM, Chang SY, Hsieh SL \& Sytwu HK 2004 Transgenic expression of decoy receptor 3 protects islets from spontaneous and chemical-induced autoimmune destruction in nonobese diabetic mice. Journal of Experimental Medicine 199 1143-1151. (doi:10.1084/jem.20031939)

Sytwu HK, Lin WD, Roffler SR, Hung JT, Sung HS, Wang CH, Cheng TL, Tsou SC, Hsi SC \& Shen KL 2003 Anti-4-1BB-based immunotherapy for autoimmune diabetes: lessons from a transgenic non-obese diabetic (NOD) model. Journal of Autoimmunity 21 247-254. (doi:10.1016/S0896-8411(03) 00112-4)

Todorov I, Omori K, Pascual M, Rawson J, Nair I, Valiente L, Vuong T, Matsuda T, Orr C, Ferreri K et al. 2006 Generation of human islets through expansion and differentiation of non-islet pancreatic cells discarded (pancreatic discard) after islet isolation. Pancreas 32 130-138. (doi:10.1097/ 01.mpa.0000202945.78331.93)

Treutelaar MK, Skidmore JM, Dias-Leme CL, Hara M, Zhang L, Simeone D, Martin DM \& Burant CF 2003 Nestin-lineage cells contribute to the microvasculature but not endocrine cells of the islet. Diabetes $\mathbf{5 2}$ 2503-2512. (doi:10.2337/diabetes.52.10.2503)

Wang HS, Shen WS, Hsu HC, Chi TC, Chen CP, Shyu JF, Huang SW, Shyr YM, Tang KT \& Chen TH 2010 Transplantation of insulin producing cells derived from umbilical cord stromal mesenchymal stem cells to treat NOD mice. Cell Transplantation (In Press). (doi:10.3727/ 096368910X522270)

Wu LF, Wang NN, Liu YS \& Wei X 2009 Differentiation of Wharton's Jelly primitive stromal cells into insulin-producing cells in comparison with bone marrow mesenchymal stem cells. Tissue Engineering. Part A $\mathbf{1 5}$ 2865-2873. (doi:10.1089/ten.tea.2008.0579)

Yamaoka T 2002 Regeneration therapy of pancreatic $\beta$ cells: towards a cure for diabetes? Biochemical and Biophysical Research Communications 296 1039-1043. (doi:10.1016/S0006-291X(02)02000-4)

Zulewski H, Abraham EJ, Gerlach MJ, Daniel PB, Moritz W, Müller B, Vallejo M, Thomas MK \& Habener JF 2001 Multipotential nestin-positive stem cells isolated from adult pancreatic islets differentiate ex vivo into pancreatic endocrine, exocrine, and hepatic phenotypes. Diabetes $\mathbf{5 0}$ 521-533. (doi:10.2337/diabetes.50.3.521)

\section{Received in final form 26 November 2010 \\ Accepted 13 December 2010 Made available online as an Accepted Preprint 13 December 2010}

